\title{
Physicochemical Parameters, Mineral Composition, and Nutraceutical Properties of Ready-to-Drink Flavored-Colored Commercial Teas
}

\author{
Daniel Flores-Martínez, ${ }^{1}$ Vania Urías-Orona, ${ }^{2}$ Luis Hernández-García, ${ }^{3}$ \\ Werner Rubio-Carrasco, ${ }^{4}$ Korev Silva-Gutiérrez, ${ }^{1}$ Michelle Guevara-Zambrano, ${ }^{1}$ \\ Julio Prieto-Cadena, ${ }^{1}$ Teresa Serna-Méndez, ${ }^{1}$ Dolores Muy-Rangel $\left(\mathbb{D},{ }^{4}\right.$ \\ and Guillermo Niño-Medina $\mathbb{D i}^{1}$ \\ ${ }^{1}$ Laboratorio de Química y Bioquímica, Facultad de Agronomía, Universidad Autónoma de Nuevo León, Francisco Villa S/N, \\ Col. Ex-Hacienda El Canadá, 66050 General Escobedo, NL, Mexico \\ ${ }^{2}$ Laboratorio de Química de Alimentos, Facultad de Salud Pública y Nutrición, Universidad Autónoma de Nuevo León, \\ Av. Dr. Eduardo Aguirre Pequeño y Yuriria, Col. Mitras Centro, 64460 Monterrey, NL, Mexico \\ ${ }^{3}$ Catedrático CONACYT-Centro de Investigación e Innovación Tecnológica, Instituto Tecnológico de Nuevo León, \\ Av. De la Alianza No. 507, PIIT, Carretera Monterrey-Aeropuerto Km. 10, 66628 Apodaca, NL, Mexico \\ ${ }^{4}$ Laboratorio de Tecnología de Alimentos, Centro de Investigación en Alimentación y Desarrollo, A.C. Coordinación Culiacán, \\ Carretera a Culiacán-El Dorado, km. 5.5, 80129 Culiacán, SIN, Mexico
}

Correspondence should be addressed to Dolores Muy-Rangel; mdmuy@ciad.mx and Guillermo Niño-Medina; guillermo.ninomd@uanl.edu.mx

Received 16 February 2018; Revised 14 May 2018; Accepted 11 June 2018; Published 2 August 2018

Academic Editor: Branca Silva

Copyright () 2018 Daniel Flores-Martínez et al. This is an open access article distributed under the Creative Commons Attribution License, which permits unrestricted use, distribution, and reproduction in any medium, provided the original work is properly cited.

The physicochemical parameters, mineral composition, and nutraceutical properties of ready-to-drink flavored-colored commercial teas were analyzed in the present study. The $\mathrm{pH}$ of samples was slightly acidic (3.72 to 4.11 ), titratable acidity was low (0.092 to $0.174 \%)$, and color parameters were wide variable (pink, yellow, brown, and red). Citrus-flavored tea obtained the highest content of manganese $\left(0.281 \mathrm{mg} \cdot \mathrm{L}^{-1}\right)$, zinc $\left(0.069 \mathrm{mg} \cdot \mathrm{L}^{-1}\right)$, magnesium $\left(2.92 \mathrm{mg} \cdot \mathrm{L}^{-1}\right)$, potassium $\left(62.65 \mathrm{mg} \cdot \mathrm{L}^{-1}\right)$, and sodium $\left(271.74 \mathrm{mg} \cdot \mathrm{L}^{-1}\right)$, while lemon-, peach-, and blueberry-flavored teas obtained the highest levels of copper $\left(0.035 \mathrm{mg} \cdot \mathrm{L}^{-1}\right)$, iron $\left(0.246 \mathrm{mg} \cdot \mathrm{L}^{-1}\right)$, and calcium $\left(18.21 \mathrm{mg} \cdot \mathrm{L}^{-1}\right)$, respectively. Citrus, lemon-, sangria-, and rose petal-flavored teas obtained the highest content in total phenols $\left(211.56 \mathrm{mg} \cdot \mathrm{L}^{-1}\right)$, total flavonoids $\left(65.46 \mathrm{mg} \cdot \mathrm{L}^{-1}\right)$, total catechins $\left(640.79 \mathrm{mg} \cdot \mathrm{L}^{-1}\right)$, and total anthocyanins $\left(640.79 \mathrm{mg} \cdot \mathrm{L}^{-1}\right)$, respectively. Lemon- and rose petal-flavored teas showed the highest and lowest antioxidant capacity levels in DPPH (1096.00 to $118.77 \mu \mathrm{molTE} \cdot \mathrm{L}^{-1}$ ), ABTS $\left(1048.84\right.$ to $232.00 \mu \mathrm{molTE} \cdot \mathrm{L}^{-1}$ ), and FRAP (1269.20 to $\left.147.70 \mu \mathrm{molTE} \cdot \mathrm{L}^{-1}\right)$ assays. The levels of sodium reported in labels of all samples were lower than data obtained in our analysis. Also the levels observed for total phenols in blueberry-, citrus-, and rose petal-flavored teas were lower than our analysis, but total phenols of lemon-, peach-, and sangria-flavored teas were higher than the content reported in their labels. The results obtained in the present work give information to consumers for choosing flavored-colored ready-to-drink tea based on the physicochemical, nutritional, and nutraceutical properties.

\section{Introduction}

Tea (Camellia sinensis (L.) O. Kuntze) belongs to the genus Camellia, family Theacea and is native of Southeast Asia. It is the oldest nonalcoholic beverage and the most consumed plant-based beverage in the world. The chemical composition of tea varies with the species, season, age of the leaves, climate, and horticultural practices $[1,2]$. Tea is classified into white, green, oolong tea, black, and red (puerh tea) according to the production process. White tea is produced from very young immature leaves and buds that have not yet turned green and once harvested is simply 
withered and dried by steaming. Green tea is produced from mature leaves with minimal processing; the tea leaves are usually heated with rolling immediately after harvest to inactivate the enzyme polyphenol oxidize. Black tea is produced from fully fermented mature leaves; the enzyme is allowed to act in a way that the leaves are fully fermented to give aroma and color. Oolong tea is produced from partially fermented mature leaves and is allotted limited time of oxidation and is thus less fermented than black tea [2-4]. In the production of red tea $(\mathrm{Pu}$-erh tea), the dried green tea leaves are artificially postfermented with microorganisms for several months to one year to produce ripened $\mathrm{Pu}$-erh tea [5]. The regular consumption of tea contributes significantly to the required daily total water intake, and if sugar is not added, the intake of calories is insignificant. The contribution of minerals and phenolics from tea is more relevant than other nonalcoholic beverages widely consumed, and their concentration in brewed products varies with solvent used for extraction $[6,7]$. The consumption of tea is equally divided between the hot and the ready-to-drink products in most of the Western countries, but this balance shifts drastically to an increase in the consumption of ready-todrink tea during the spring and summer [8]. In addition, the global ready-to-drink tea market increased from 26 billion liters in 2011 to 37 billion liters in 2016 and is expected to reach 45 billion liters in 2021. Lemon is the most popular ready-to-drink tea flavor followed by peach, but the use of new flavors (exotic flavors specially) is increasing globally. Asia has the $72 \%$ of the ready-to-drink global market, followed by North America with 15\%, Europe with 9\%, and Middle East, Africa, and Latin America together accounted for the $4 \%$ [9].

Due to the increasing interest of consumers in the consumption of ready-to-drink teas with different flavors and colors, it is necessary to know about their physicochemical, nutritional, and nutraceutical characteristics. The aim of this work was to evaluate the physicochemical parameters, mineral composition, and nutraceutical properties of six ready-to-drink flavored-colored commercial teas available in Mexico.

\section{Materials and Methods}

2.1. Ready-to-Drink Tea Samples. Three samples of $485 \mathrm{~mL}$ from different lot number of six commercial ready-to-drink flavored-colored teas (blueberry, citrus, lemon, peach, rose petal and sangria) were purchased in a local supermarket in the first week of February 2017. Composition of ready-todrink teas according to their nutrition fact labels is presented in Table 1.

2.2. Physicochemical Parameters. For the measurement of $\mathrm{pH}$ and titratable acidity, $10 \mathrm{~mL}$ of sample was diluted with $40 \mathrm{~mL}$ of distilled water, and the $\mathrm{pH}$ was read. After that, samples were titrated with $0.1 \mathrm{M} \cdot \mathrm{NaOH}$ to a $\mathrm{pH}$ of 8.2 (citric acid as predominant) using a Mettler-Toledo automatic T50 titrator (Greifensee, Switzerland) according to the Association of Official Analytical Chemists methods [10].
TABLE 1: Composition of ready-to-drink flavored-colored commercial teas.

\begin{tabular}{|c|c|}
\hline Tea flavor & Composition reported in label \\
\hline Blueberry & $\begin{array}{c}\text { Water, white tea extract (Camellia sinensis), citric } \\
\text { acid, sodium citrate, sucralose, colorant } \\
\text { (anthocyanins and carmine), white tea flavor, } \\
\text { blueberry flavor, sodium } 100 \mathrm{mg} \cdot \mathrm{L}^{-1} \text {, and } \\
\text { polyphenols } 125 \mathrm{mg} \cdot \mathrm{L}^{-1} \text {. }\end{array}$ \\
\hline Citrus & $\begin{array}{l}\text { Water, green tea extract (Camellia sinensis), citric } \\
\text { acid, sodium citrate, concentrated lemon juice, } \\
\text { colorant (class IV caramel), green tea flavor, lemon } \\
\text { flavor, sodium } 150 \mathrm{mg} \cdot \mathrm{L}^{-1} \text {, and polyphenols } \\
225 \mathrm{mg} \cdot \mathrm{L}^{-1} \text {. }\end{array}$ \\
\hline Lemon & $\begin{array}{c}\text { Water, black tea extract (Camellia sinensis), citric } \\
\text { acid, sodium citrate, sucralose, concentrated lemon } \\
\text { juice, colorant (class IV caramel and anthocyanins), } \\
\text { black tea flavor, lemon flavor, sodium } 150 \mathrm{mg} \cdot \mathrm{L}^{-1} \text {, } \\
\text { and polyphenols } 125 \mathrm{mg} \cdot \mathrm{L}^{-1} \text {. }\end{array}$ \\
\hline Peach & $\begin{array}{l}\text { Water, black tea extract (Camellia sinensis), citric } \\
\text { acid, sodium citrate, sucralose, colorant (class IV } \\
\text { caramel and anthocyanins), black tea flavor, peach } \\
\text { flavor, sodium } 50 \mathrm{mg} \cdot \mathrm{L}^{-1} \text {, and polyphenols } 55 \mathrm{mg} \cdot \mathrm{L}^{-1} \text {. }\end{array}$ \\
\hline Rose petal & $\begin{array}{l}\text { Water, red tea extract (Camellia sinensis), citric acid, } \\
\text { sodium citrate, sucralose, colorant (class IV caramel } \\
\text { and anthocyanins), red tea flavor, rose petal flavor, } \\
\text { sodium } 125 \mathrm{mg} \cdot \mathrm{L}^{-1} \text {, and polyphenols } 50 \mathrm{mg} \cdot \mathrm{L}^{-1} \text {. }\end{array}$ \\
\hline Sangria & $\begin{array}{l}\text { Water, red tea extract and black tea extract (Camellia } \\
\text { sinensis), citric acid, sodium citrate, sucralose, } \\
\text { colorant (class IV caramel and anthocyanins), red tea } \\
\text { flavor, sangria flavor, sodium } 150 \mathrm{mg} \cdot \mathrm{L}^{-1} \text {, and } \\
\text { polyphenols } 50 \mathrm{mg} \cdot \mathrm{L}^{-1} \text {. }\end{array}$ \\
\hline
\end{tabular}

For color determination, a $1.5 \mathrm{~mL}$ spectrophotometric cuvette was filled with sample, and color was determined using a CR-20 Konica Minolta Color Reader (Tokyo, Japan). Chromatic parameters were obtained using CIELAB $\left(L^{*}\right.$, $\left.a^{*}, b^{*}\right)$ and $\operatorname{CIELCH}\left(L^{*}, C^{*}, h\right)$ color systems according to Commission Internationale De L'ecleirage [11]. $L^{*}$ defines lightness $\left(0=\right.$ black, $100=$ white), $a^{*}$ indicates red (positive $a^{*}$ ) or green value (negative $a^{*}$ ) and $b^{*}$ indicates yellow (positive $b^{*}$ ) or blue value (negative $b^{*}$ ), $C^{*}$ (chroma; saturation level of $h$ ) and $h$ (hue angle: $0^{\circ}=$ red, $90^{\circ}=$ yellow, $180^{\circ}=$ green, $270^{\circ}=$ blue). . Color view was obtained by online software ColorHexa color converter using $L^{*}, a^{*}$, and $b^{*}$ values [12].

2.3. Mineral Composition. Mineral analysis was done based on AOAC [10] methods using an Agilent Atomic Absorption 240FS spectrometer (Santa Clara, United States). Briefly, $5 \mathrm{~mL}$ of $3 \mathrm{M} \cdot \mathrm{HCl}$ was added to $50 \mathrm{~mL}$ of tea sample and digested-evaporated at boiling temperature until $20 \mathrm{~mL}$ of sample was obtained. Afterwards, samples were filtered and used for mineral analysis. Potassium and sodium were detected by emission at wavelengths of 589.6 and $769.9 \mathrm{~nm}$, respectively, while calcium, magnesium, iron, zinc, copper, and manganese were determined by absorption at wavelengths of $422.7,285.2,248.3,213.9,324.7$, and $279.5 \mathrm{~nm}$, respectively.

The results were expressed as milligrams per liter of sample $\left(\mathrm{mg} \cdot \mathrm{L}^{-1}\right)$ based on calibration curves prepared with 
standards of each mineral ( 0 to $100 \mathrm{mg} \cdot \mathrm{L}^{-1}$ for sodium and potassium; 0-10 mg. $\mathrm{L}^{-1}$ for calcium, magnesium, iron, and manganese; and 0 to $5 \mathrm{mg} \cdot \mathrm{L}^{-1}$ for zinc and copper).

2.4. Nutraceutical Properties. Total phenols, total flavonoids, total catechins, DPPH, and ABTS were carried out according to Niño-Medina et al. [13], and total anthocyanins content was measured according to Abdel-Aal and Hucl [14], while FRAP was carried out according to López-Contreras et al. [15]. Phenolics and antioxidant capacity assays were performed in a Barnstead International Turner SP-830 Plus spectrophotometer (Dubuque, United States).

The content of total phenols was determined based on the reaction of Folin-Ciocalteu reagent. Briefly, $0.2 \mathrm{~mL}$ of tea sample was placed in $2.6 \mathrm{~mL}$ of distilled water, oxidized with $0.2 \mathrm{~mL}$ of Folin-Ciocalteu reagent, and after $5 \mathrm{~min}$, neutralized with $2 \mathrm{~mL}$ of $7 \% \mathrm{Na}_{2} \mathrm{CO}_{3}$ solution. The reaction was left for $90 \mathrm{~min}$, and finally, the absorbance of sample was measured at $750 \mathrm{~nm}$. Gallic acid was used as the standard (0 to $200 \mathrm{mg} \cdot \mathrm{L}^{-1}$ ), and the results were expressed as milligrams of gallic acid equivalent per liter of sample $\left(\mathrm{mgGAE} \cdot \mathrm{L}^{-1}\right)$.

The content of total flavonoids was evaluated based on the reaction of aluminum chloride. Briefly, $0.2 \mathrm{~mL}$ of phenolic extract was placed in $3.5 \mathrm{~mL}$ of distilled water, followed by $0.15 \mathrm{~mL}$ of $5 \% \mathrm{NaNO}_{2}$. After $5 \mathrm{~min}, 0.15 \mathrm{~mL}$ of $10 \% \mathrm{AlCl}_{3}$ was added, and $5 \mathrm{~min}$ later, $1.0 \mathrm{~mL}$ of $1 \mathrm{M} \cdot \mathrm{NaOH}$ was added. Reaction was left for $15 \mathrm{~min}$, and finally, the absorbance of sample was measured at $510 \mathrm{~nm}$. Catechin was used as the standard ( 0 to $200 \mathrm{mg} \cdot \mathrm{L}^{-1}$ ), and the results were expressed as milligrams of catechin equivalents per liter of sample $\left(\mathrm{mgCatE} \cdot \mathrm{L}^{-1}\right)$.

The content of total catechins was determined based on the reaction of vanillin- $\mathrm{H}_{2} \mathrm{SO}_{4}$. Briefly, $0.25 \mathrm{~mL}$ of phenolic extract was mixed with $0.65 \mathrm{~mL}$ of $1 \%$ vanillin solution and $0.65 \mathrm{~mL}$ of $25 \% \mathrm{H}_{2} \mathrm{SO}_{4}$ (both dissolved in methanol). Reaction was left for $15 \mathrm{~min}$ at $30^{\circ} \mathrm{C}$, and finally, the absorbance of sample was measured at $500 \mathrm{~nm}$. Catechin was used as the standard ( 0 to $200 \mathrm{mg} \cdot \mathrm{L}^{-1}$ ), and the results were expressed as milligrams of catechin equivalents per liter of sample $\left(\mathrm{mgCatE} \cdot \mathrm{L}^{-1}\right)$.

For anthocyanins content, $200 \mu \mathrm{L}$ of tea sample was mixed with $10 \mathrm{~mL}$ of ethanol- $\mathrm{HCl}\left(85: 15 \mathrm{v} / \mathrm{v}, \mathrm{pH} 1,4^{\circ} \mathrm{C}\right)$ and shaken at $200 \mathrm{rpm}$ for $30 \mathrm{~min}$. Afterwards, the sample was centrifuged at $1000 \mathrm{rpm}$ for $15 \mathrm{~min}$, and finally, $3.5 \mathrm{~mL}$ of sample was measured at $535 \mathrm{~nm}$. The content of anthocyanins was reported as milligrams of cyanidin-3-glucoside (C3G) per liter of sample $\left(\mathrm{mgC} 3 \mathrm{GE} \cdot \mathrm{L}^{-1}\right)$ using the following formula:

$$
C=\left(\frac{A}{\varepsilon}\right) *\left(\frac{V}{1000}\right) * \mathrm{MW} *\left(\frac{1}{\text { weight of sample }}\right) * 10^{6}
$$

where $C=$ concentration in $\mathrm{mgC} 3 \mathrm{GE} \cdot \mathrm{L}^{-1}, A=$ absorbance of sample, $\varepsilon=$ molar absorptivity $\left(\mathrm{C} 3 \mathrm{G}=26965 \mathrm{~cm}^{-1} \cdot \mathrm{mol}^{-1}\right)$, $\mathrm{V}=$ volume of sample, and $\mathrm{MW}=$ molecular weight of $\mathrm{C} 3 \mathrm{G}$ $\left(449.2 \mathrm{~g} \mathrm{~mol}^{-1}\right)$.

The DPPH (2,2-diphenyl-1-picrylhydrazyl) antioxidant capacity was evaluated using a working solution $60 \mu \mathrm{M}$ (in methanol) with an absorbance adjusted to 0.7 at $517 \mathrm{~nm}$. The assay was carried out by mixing $0.2 \mathrm{~mL}$ of tea sample with $3.3 \mathrm{~mL}$ of the $\mathrm{DPPH}$ working solution, the reaction was left for $30 \mathrm{~min}$ in the dark, and the absorbance was determined.

The ABTS (3-ethyl-benzothiazoline-6-sulfonic acid) antioxidant capacity was carried out using a working solution obtained by mixing one $\mathrm{mL} 7.4 \mathrm{mM}$ of ABTS and one $\mathrm{mL}$ of $2.6 \mathrm{mM}$ of $\mathrm{K}_{2} \mathrm{~S}_{2} \mathrm{O}_{8}$ and allowing them to react for $12 \mathrm{~h}$ in the dark. After that, the absorbance of working solution was adjusted to 0.7 at $734 \mathrm{~nm}$ diluting with methanol. The ABTS assay was performed by mixing $0.2 \mathrm{~mL}$ of the tea sample with $3.3 \mathrm{~mL}$ of ABTS working solution; the reaction was left for $30 \mathrm{~min}$ in the dark, and the absorbance was measured.

The FRAP (ferric reducing antioxidant power) antioxidant capacity was determined using a working solution prepared by mixing $300 \mathrm{mM} \cdot \mathrm{C}_{2} \mathrm{H}_{3} \mathrm{NaO}_{2} \cdot 3 \mathrm{H}_{2} \mathrm{O}(\mathrm{pH}$ 3.6), $10 \mathrm{mM} \cdot \mathrm{TPTZ}$ (2,4,6-tripyridyl-s-triazine, in $\mathrm{HCl} 40 \mathrm{mM}$ ), and $20 \mathrm{mM} \mathrm{FeCl}_{3} \cdot 6 \mathrm{H}_{2} \mathrm{O}$ in $10: 1: 1(\mathrm{~V}: \mathrm{V}: \mathrm{V})$ proportion. The FRAP assay was prepared by mixing $0.2 \mathrm{~mL}$ of tea sample with $3.3 \mathrm{~mL}$ of FRAP working solution, the reaction was left for $30 \mathrm{~min}$ in the dark at $37^{\circ} \mathrm{C}$, and the absorbance of samples was taken at $593 \mathrm{~nm}$.

Trolox (6-hydroxy-2,5,7,8-tetramethylchroman-2-carboxylic acid) was used as standard ( 0 to $200 \mu \mathrm{mol} \cdot \mathrm{L}^{-1}$ ) for $\mathrm{DPPH}$, ABTS, and FRAP assays, and the results were expressed as micromoles of trolox equivalent per gram of sample $\left(\mu \mathrm{mol} \cdot \mathrm{L}^{-1}\right)$.

2.5. Statistical Analysis. Results were expressed as mean values of three samples \pm standard deviation. Statistical significance between samples was evaluated by analysis of variance followed by Tukey's test using Minitab 14.0. A probability of $p \leq 0.05$ (5\%) was deemed to be statistically significant.

\section{Results and Discussion}

3.1. Physicochemical Parameters. The $\mathrm{pH}$ and titratable acidity are analytically determined in separate ways, and each has its own particular impact on food quality [16].

Titratable acidity is a better predictor of the impact of acid content on flavor of food, and the $\mathrm{pH}$ is a better predictor of the ability of a microorganism to grow in a specific food [17]. On the other hand, color is the first notable characteristic of a food and often predetermines our expectation. Natural and synthetic colors play several roles in foods and beverages. Consumers use color as a way to identify a food and a way to judge the quality of a food [18].

There were statistical differences $(p<0.05)$ between tea samples in physicochemical parameters (Table 2 ). The values of $\mathrm{pH}$ in tea samples were slightly acidic and ranged from 3.72 to 4.11 while titratable acidity ranged from 0.0092 to $0.174 \%$. Chromatic values ranged from 25.1 to $53.9,12.3$ to $30.5,18.1$ to $32.0,25.3$ to 36.9 , and 27.0 to 68.3 in $L^{*}, a^{*}, b^{*}$, $C^{*}$, and $h$, respectively, and color views were wide variable with samples in pink, yellow, brown, and red colors. 
TABLe 2: Physicochemical parameters of ready-to-drink flavored-colored commercial teas.

\begin{tabular}{|c|c|c|c|c|c|c|c|c|}
\hline \multirow{2}{*}{ Tea flavor } & \multirow{2}{*}{$\mathrm{pH}$} & \multirow{2}{*}{ TA (\%) } & \multicolumn{6}{|c|}{ Chromatic characteristics } \\
\hline & & & $L^{*}$ & $a^{*}$ & $b^{*}$ & $C^{*}$ & $h$ & View \\
\hline Blueberry & $4.11 \pm 0.007^{\mathrm{a}}$ & $0.105 \pm 0.0014^{\mathrm{d}}$ & $49.8 \pm 0.14^{\mathrm{b}}$ & $22.6 \pm 0.07^{\mathrm{b}}$ & $11.5 \pm 0.07^{\mathrm{e}}$ & $25.3 \pm 0.07^{c}$ & $27.0 \pm 0.21^{\mathrm{e}}$ & \\
\hline Citrus & $4.09 \pm 0.003^{\mathrm{a}}$ & $0.135 \pm 0.0007^{c}$ & $53.9 \pm 0.99^{\mathrm{a}}$ & $4.7 \pm 0.65^{\mathrm{d}}$ & $26.1 \pm 0.64^{\mathrm{c}}$ & $26.6 \pm 0.64^{\mathrm{c}}$ & $79.1 \pm 0.28^{\mathrm{a}}$ & \\
\hline Lemon & $3.85 \pm 0.009^{c}$ & $0.174 \pm 0.0014^{\mathrm{a}}$ & $39.3 \pm 0.42^{c}$ & $12.7 \pm 0.14^{\mathrm{c}}$ & $32.0 \pm 0.35^{\mathrm{a}}$ & $34.4 \pm 0.28^{\mathrm{a}}$ & $68.3 \pm 0.28^{\mathrm{b}}$ & \\
\hline Peach & $3.72 \pm 0.007^{\mathrm{d}}$ & $0.151 \pm 0.0014^{\mathrm{b}}$ & $38.0 \pm 0.35^{\mathrm{c}}$ & $12.3 \pm 0.07^{\mathrm{c}}$ & $28.2 \pm 0.21^{\mathrm{b}}$ & $30.7 \pm 0.14^{\mathrm{b}}$ & $66.5 \pm 0.14^{c}$ & \\
\hline Rose petal & $3.97 \pm 0.018^{\mathrm{b}}$ & $0.092 \pm 0.0007^{\mathrm{e}}$ & $26.7 \pm 0.78^{\mathrm{d}}$ & $30.5 \pm 1.20^{\mathrm{a}}$ & $20.3 \pm 1.91^{\mathrm{d}}$ & $36.6 \pm 1.84^{\mathrm{a}}$ & $33.6 \pm 0.35^{\mathrm{d}}$ & \\
\hline Sangria & $3.82 \pm 0.005^{\mathrm{c}}$ & $0.147 \pm 0.0007^{\mathrm{b}}$ & $25.1 \pm 0.14^{\mathrm{d}}$ & $28.0 \pm 0.78^{\mathrm{a}}$ & $18.1 \pm 0.78^{\mathrm{d}}$ & $33.3 \pm 1.06^{\mathrm{ab}}$ & $32.9 \pm 0.49^{\mathrm{d}}$ & \\
\hline
\end{tabular}

Values with different letters within same evaluation are significantly different $(p<0.05, n=3)$.

TABLE 3: Mineral composition of ready-to-drink flavored-colored commercial teas.

\begin{tabular}{|c|c|c|c|c|c|c|c|c|}
\hline \multirow{2}{*}{ Tea flavor } & \multicolumn{4}{|c|}{ Minor elements $\left(\mathrm{mg} \cdot \mathrm{L}^{-1}\right)$} & \multicolumn{4}{|c|}{ Major elements $\left(\mathrm{mg} \cdot \mathrm{L}^{-1}\right)$} \\
\hline & $\mathrm{Cu}$ & $\mathrm{Mn}$ & $\mathrm{Zn}$ & $\mathrm{Fe}$ & $\mathrm{Ca}$ & $\mathrm{Mg}$ & $\mathrm{K}$ & $\mathrm{Na}$ \\
\hline Blueberry & $0.013 \pm 0.004^{\mathrm{bc}}$ & ND & $039 \pm 0.003^{\mathrm{bc}}$ & $0.134 \pm 0.007^{\mathrm{ab}}$ & $18.21 \pm 0.27^{\mathrm{a}}$ & $1.33 \pm 0.01^{\mathrm{c}}$ & $20.27 \pm 0.17^{\mathrm{e}}$ & $210.60 \pm 0.77^{\mathrm{b}}$ \\
\hline Citr & $0.030 \pm 0.001^{\mathrm{ab}}$ & $0.281 \pm 0.003^{\mathrm{a}}$ & $0.069 \pm 0.001^{\mathrm{a}}$ & $0.072 \pm 0.008^{\mathrm{bc}}$ & $15.05 \pm 0.07^{\mathrm{b}}$ & $2.92 \pm 0.01^{\mathrm{a}}$ & $62.65 \pm 0.28^{\mathrm{a}}$ & $271.74 \pm 3.64^{\mathrm{a}}$ \\
\hline Lemon & $0.035 \pm 0.001^{\mathrm{a}}$ & $0.036 \pm 0.007^{\mathrm{b}}$ & $0.037 \pm 0.006^{\mathrm{bc}}$ & $0.142 \pm 0.048^{\mathrm{abc}}$ & $14.59 \pm 0.02^{\mathrm{C}}$ & $1.83 \pm 0.05^{\mathrm{b}}$ & $53.38 \pm 0.62^{\mathrm{b}}$ & $259.17 \pm 9.77^{\mathrm{a}}$ \\
\hline Peach & $0.033 \pm 0.003^{\mathrm{ab}}$ & ND & $0.043 \pm 0.007^{\mathrm{bc}}$ & $0.246 \pm 0.040^{\mathrm{a}}$ & $14.49 \pm 0.67^{\mathrm{bc}}$ & $1.45 \pm 0.18^{\mathrm{bc}}$ & $30.93 \pm 0.40^{\mathrm{d}}$ & $183.68 \pm 2.95^{\mathrm{c}}$ \\
\hline Rose petal & $0.024 \pm 0.001^{\mathrm{b}}$ & ND & $0.049 \pm 0.001^{\mathrm{b}}$ & $0.061 \pm 0.001^{c}$ & $15.45 \pm 0.17^{\mathrm{bc}}$ & $0.84 \pm 0.01^{\mathrm{d}}$ & $20.64 \pm 0.43^{\mathrm{e}}$ & $180.70 \pm 2.82^{\mathrm{C}}$ \\
\hline Sangria & $0.018 \pm 0.003^{b}$ & ND & $0.036 \pm 0.001^{c}$ & $0.100 \pm 0.021^{\mathrm{b}}$ & $15.79 \pm 0.36^{\mathrm{bc}}$ & $0.99 \pm 0.04^{\mathrm{d}}$ & $44.56 \pm 0.29^{c}$ & $194.51 \pm 7.48^{\mathrm{bc}}$ \\
\hline
\end{tabular}

Values with different letters within same evaluation are significantly different $(p<0.05, n=3)$. ND = not detected.

The results of the present study show higher $\mathrm{pH}$ values than data reported by Lunkes and Hashizume [19], whom analyzed 11 commercial ready-to-drink flavored teas available in Brazil market and found $\mathrm{pH}$ values ranging from 2.89 to 3.41 . In addition, the titratable acidity reported by these authors was higher than our observations, since they found values ranging from 0.193 to $0.325 \%$.

On the other hand, Lin et al. [20] prepared green tea infusions from cold and hot brewed-parched or brewedsteamed green tea at 2, 6, and $10 \%(\mathrm{w} / \mathrm{v})$ and obtained $\mathrm{pH}$ values from 5.47 to 5.88 which are higher values than all of the samples analyzed in the present study. They also measured the chromatic properties of tea infusions, and their data in $b^{*}$ values were close to our observations (7.40 to 34.7 ), most of their $L^{*}$ values (75.9 to 92.9 ) were higher than our samples, and most of their $a^{*}$ values $(-0.76$. to 9.52) were lower than our results.

The differences in the $\mathrm{pH}$ and titratable acidity values between these authors and our study are attributed to the fact that commercial available ready-to-drink teas contain citric acid as acidifier and sodium citrate as $\mathrm{pH}$ stabilizer to extend the shelf life of product. On the other hand, all samples analyzed in our study reported the use of colorants in their formulations (anthocyanins, carmine, and class IV caramel) which modify the original color of the beverage lowering the $L^{*}$ value.

3.2. Mineral Composition. Minerals are crucial for the interaction between genetic and physiological factors. If a dietary deficiency of these elements exists, it will lead to physiological and structural abnormalities that are preventable and which may be reversed by administration of the element. Calcium, magnesium, sodium, potassium, iron, and zinc are essential elements, while copper and manganese are trace elements [21].

There were statistical differences $(p<0.05)$ between tea samples as in minor and as in major elements (Table 3). Different from the rest of the elements, manganese was detected only in citrus-flavored $\left(0.281 \mathrm{mg} \cdot \mathrm{L}^{-1}\right)$ and lemonflavored teas $\left(0.0036 \mathrm{mg} \cdot \mathrm{L}^{-1}\right)$. Citrus-flavored tea obtained the highest content of manganese, zinc, magnesium, potassium, and sodium, while lemon, peach, and blueberry teas obtained the highest levels of copper, iron, and calcium, respectively. Sodium (180 to $271 \mathrm{mg} \cdot \mathrm{L}^{-1}$ ) was the mineral found in highest amount in samples followed by potassium (20 to $62 \mathrm{mg} \cdot \mathrm{L}^{-1}$ ) and calcium (14 to $18 \mathrm{mg} \cdot \mathrm{L}^{-1}$ ), while copper $\left(0.018\right.$ to $\left.0.035 \mathrm{mg} \cdot \mathrm{L}^{-1}\right)$ was the lower element in all samples.

A wide range of selected micronutrient in made tea has been found in literature. The difference in micronutrient content of made teas could be attributed to the tea produced in different growing areas of the world having high variation in micronutrient contents, which resulted in differential micronutrient uptake by tea plants [22].

There is no literature available for comparison with the current report as there are no studies on the evaluation of mineral content of commercially ready-to-drink teas. Nevertheless, several studies have evaluated the mineral composition of prepared tea infusions. Reto et al. [23], prepared tea infusions by boiling $1.5 \mathrm{~g}$ of green tea in $250 \mathrm{~mL}$ of boiling water for $10 \mathrm{~min}$ obtaining levels of calcium (1.9 to $3.5 \mathrm{mg} \cdot \mathrm{L}^{-1}$ ), potassium (92 to $15 \mathrm{mg} \cdot \mathrm{L}^{-1}$ ), sodium (35 to $\left.69 \mathrm{mg} \cdot \mathrm{L}^{-1}\right)$, and iron $\left(0.02\right.$ to $\left.0.12 \mathrm{mg} \cdot \mathrm{L}^{-1}\right)$. These values were lower than the flavored teas analyzed in the present study, but the content of manganese $\left(0.5\right.$ to $\left.1.9 \mathrm{mg} \cdot \mathrm{L}^{-1}\right)$ reported by these authors was higher than all our samples.

Gallaher et al. [24], prepared green tea infusions (Chinese, decaffeinated, and authentic) by stirring $2 \mathrm{~g}$ of tea 
TABLE 4: Nutraceutical properties of ready-to-drink flavored-colored commercial teas.

\begin{tabular}{lccccccc}
\hline \multirow{2}{*}{ Tea flavor } & \multicolumn{3}{c}{ Phenolics $\left(\mathrm{mg} \cdot \mathrm{L}^{-1}\right)$} & \multicolumn{3}{c}{ Antioxidant capacity $\left(\mu \mathrm{molTE} \cdot \mathrm{L}^{-1}\right)$} \\
& Total phenols & Total flavonoids & Total catechins & Total anthocyanins & DPPH & ABTS & FRAP \\
\hline Blueberry & $110.87 \pm 0.95^{\mathrm{c}}$ & $26.10 \pm 0.70^{\mathrm{d}}$ & $224.35 \pm 8.54^{\mathrm{c}}$ & $10.44 \pm 1.23^{\mathrm{d}}$ & $1029.21 \pm 13.67^{\mathrm{b}}$ & $1030.65 \pm 7.79^{\mathrm{a}}$ & $1143.00 \pm 72.5^{\mathrm{a}}$ \\
Citrus & $211.56 \pm 3.01^{\mathrm{a}}$ & $40.55 \pm 2.8^{\mathrm{bc}}$ & $280.68 \pm 23.71^{\mathrm{c}}$ & $15.22 \pm 0.61^{\mathrm{c}}$ & $995.81 \pm 8.70^{\mathrm{b}}$ & $1044.43 \pm 2.33^{\mathrm{a}}$ & $1170.60 \pm 69.7^{\mathrm{a}}$ \\
Lemon & $128.12 \pm 2.54^{\mathrm{b}}$ & $65.46 \pm 2.81^{\mathrm{a}}$ & $168.02 \pm 2.85^{\mathrm{d}}$ & $6.52 \pm 0.61^{\mathrm{d}}$ & $1096.00 \pm 3.73^{\mathrm{a}}$ & $1048.84 \pm 0.78^{\mathrm{a}}$ & $1269.20 \pm 18.1^{\mathrm{a}}$ \\
Peach & $75.02 \pm 1.58^{\mathrm{d}}$ & $20.62 \pm 1.41^{\mathrm{e}}$ & $165.33 \pm 4.74^{\mathrm{d}}$ & $7.39 \pm 0.61^{\mathrm{d}}$ & $754.14 \pm 2.49^{\mathrm{c}}$ & $904.98 \pm 7.79^{\mathrm{b}}$ & $766.40 \pm 79.00^{\mathrm{b}}$ \\
Rose petal & $32.35 \pm 1.11^{\mathrm{f}}$ & $37.06 \pm 0.70^{\mathrm{c}}$ & $552.27 \pm 13.28^{\mathrm{b}}$ & $182.19 \pm 10.45^{\mathrm{a}}$ & $118.77 \pm 3.53^{\mathrm{e}}$ & $232.00 \pm 11.69^{\mathrm{d}}$ & $147.70 \pm 9.70^{\mathrm{d}}$ \\
Sangria & $56.99 \pm 0.16^{\mathrm{e}}$ & $46.02 \pm 2.11^{\mathrm{b}}$ & $640.79 \pm 5.69^{\mathrm{a}}$ & $136.97 \pm 5.53^{\mathrm{b}}$ & $405.26 \pm 2.83^{\mathrm{d}}$ & $544.52 \pm 3.12^{\mathrm{c}}$ & $459.10 \pm 33.40^{\mathrm{c}}$ \\
\hline
\end{tabular}

Values with different letters within same evaluation are significantly different $(p<0.05, n=3)$.

material in $236 \mathrm{~mL}$ of boiling water for $0.5 \mathrm{~min}$ and steeped samples for 5.5 more minutes; after that, samples were evaporated to dryness, ashed at $480^{\circ} \mathrm{C}$, and $\mathrm{HCl}$-treated for mineral analysis. These authors found lower content than our samples in calcium $\left(2.24\right.$ to $\left.3.72 \mathrm{mg} \cdot \mathrm{L}^{-1}\right)$, potassium (66.22 to $\left.81.98 \mathrm{mg} \cdot \mathrm{L}^{-1}\right)$, and sodium $\left(3.89\right.$ to $\left.7.37 \mathrm{mg} \cdot \mathrm{L}^{-1}\right)$, but their content in copper $\left(0.036\right.$ to $\left.0.074 \mathrm{mg} \cdot \mathrm{L}^{-1}\right)$, magnesium (3.85 to $\left.5.29 \mathrm{mg} \cdot \mathrm{L}^{-1}\right)$, manganese (1.86 to $\left.2.48 \mathrm{mg} \cdot \mathrm{L}^{-1}\right)$, and zinc $\left(0.091\right.$ to $\left.0.137 \mathrm{mg} \cdot \mathrm{L}^{-1}\right)$ was higher. On the other hand, their content of iron (0.161 to $0.203 \mathrm{mg} \cdot \mathrm{L}^{-1}$ ) was in the range of our study.

According to the Official Mexican Standard for food labeling (NOM-051-SCFI/SSA1-2010), sodium is the only mandatory mineral that has to be reported in a food product label. The labels of all ready-to-drink teas evaluated in this study reported the content of sodium (Table 1), but the levels reported in labels were lower than data obtained in our analysis (Table 3). For instance, blueberry-, citrus-, lemon-, peach-, rose petal-, and sangria-flavored teas were 2.10-, $1.81-, 1.72-, 3.67-, 1.44-$, and 1.24-fold higher than the content reported in label, respectively. We attribute these differences to the method use in determination of sodium. In addition, the Official Mexican Standard for nonalcoholic beverages (NOM-218-SSA1-2011) indicates $600 \mathrm{mg} \cdot \mathrm{L}^{-1}$ as a maximum content of sodium in these products, and all the samples were low than this level.

3.3. Nutraceutical Properties. Phenolic compounds are receiving interest because of the recognition of their antioxidant properties, their abundance in the human diet, and their probable prevention of several diseases associated with oxidative stress [25]. In addition, it is of great interest from consumers, nutritional experts, and food science researchers to know the antioxidant capacity of the foods that we consume [26].

There were statistical differences $(p<0.05)$ between tea samples in all phenolic evaluations (Table 4). The range values of total phenols, total flavonoids, total catechins, and total anthocyanins were 32 to $211 \mathrm{mgGAE} \cdot \mathrm{L}^{-1}, 20$ to $65 \mathrm{mgCatE} \cdot \mathrm{L}^{-1}, 165$ to $640 \mathrm{mgECat} \cdot \mathrm{L}^{-1}$, and 6.52 to $182.19 \mathrm{mgC} 3 \mathrm{GE} \cdot \mathrm{L}^{-1}$, respectively. It was not a surprise that all samples were specially rich in total catechins as these compounds are the major phenolic group in tea infusions, accounting for $40 \%$ of total water-soluble solids in tea infusions [4]. The content of total catechins was higher than the content of total phenols, and although this behavior is very rare, it has been reported previously in some legumes by $\mathrm{Xu}$ and Chang [27] and Zia-Ul-Haq et al. [28]. The explanation of this behavior is that acid treatment of vanillin- $\mathrm{HCl}$ method has an effect on depolymerization of catechins, and they are quantified in more quantity than the phenolics quantified by Folin-Ciocalteu method where phenolics are not depolymerized.

Anthocyanins are not a phenolic group presented naturally in tea; nevertheless, they were quantified in all samples. This is because of the use of exogenous anthocyanins that give the characteristic color of each flavoredcolored tea. The content of total anthocyanins was higher in rose petal- and sangria-flavored teas than in the rest of the samples.

There were statistical differences $(p<0.05)$ between tea samples in all antioxidant capacity evaluations (Table 4 ). The values of antioxidant capacity were 118 to $1096 \mu \mathrm{molTE} \cdot \mathrm{L}^{-1}$, 232 to $1048 \mu \mathrm{molTE} \cdot \mathrm{L}^{-1}$, and 147 to $1269 \mu \mathrm{molTE} \cdot \mathrm{L}^{-1}$ in $\mathrm{DPPH}, \mathrm{ABTS}$, and FRAP, respectively. Rose petal- and lemon-flavored teas were the lower and higher in antioxidant capacity, respectively, in the three assays tested. The major antioxidant capacity was found in lemon-flavored tea, and this could be attributed to the antioxidant vitamins content of the concentrated lemon juice used.

To the best of our knowledge, few studies have reported the phenolic content and antioxidant capacity of commercial ready-to-drink teas. For instance, Kodama et al. [29] analyzed the phenolic content and antioxidant capacity of four ready-to-drink commercial teas available in Brazil, and they reported values around 1050 to $1705 \mathrm{mgCatE} \cdot \mathrm{L}^{-1}$ and 140,000 to $545,000 \mu \mathrm{molTE} \cdot \mathrm{L}^{-1}$ in total phenols and DPPH antioxidant capacity, respectively, being these results greatly higher than those of ours. In addition, Chen et al. [30] studied the catechin content of 14 canned and bottled green tea drinks by HPLC, and they reported values from 0.9 to $341.7 \mathrm{mg} \cdot \mathrm{L}^{-1}$ which are within the ranged content found in our samples.

On the other hand, other works have evaluated the phenolic content and antioxidant capacity of tea infusions. Lin et al. [31] prepared infusion of green, oolong, and black teas by mixing $3 \mathrm{~g}$ of tea dried tea leaves with $150 \mathrm{~mL}$ of boiling water for $5 \mathrm{~min}$, and after that, the sample was cooled to room temperature to measure the total phenols content and antioxidant capacity levels. Results obtained by these authors were higher than our results with 920, 745, and $669 \mathrm{mg} \cdot \mathrm{L}^{-1}$ of total phenols in of green, oolong, and black teas, respectively. In addition, Lin et al. [20] also obtained 
higher values than our tea samples with values ranged from 749 to $5610 \mathrm{mg} \cdot \mathrm{L}^{-1}$ in green tea infusions from cold and hot brewed-parched or brewed-steamed green tea at 2, 6, and $10 \%$ $(\mathrm{w} / \mathrm{v})$. These authors also obtained higher values than ours in infusions prepared from cold and hot brewed-parched or brewed-steamed green tea at $2 \%$ with values ranging around 332 to $781 \mathrm{mg} \cdot \mathrm{L}^{-1}$ in infusions at prepared $2 \%$.

Other studies have reported higher values than ours, and this is because teas are prepared directly from tea product at laboratory scale without the thermal process (sterilization) and dilution that is carried on the commercial industry of ready-to-drink tea.

Although the polyphenols content in food label is not mandatory in the Official Mexican Standard for food labeling (NOM-051-SCFI/SSA1-2010), all the analyzed teas reported the content of these compounds in their labels, and this is may be to make an impact on the consumers about the functional food ingredients in the product. Comparing the content reported in label against our data in total phenols, blueberry-, citrus-, and rose petal-flavored teas were 1.12, 1.06 , and $1.54 \%$ lower than the content reported in their labels. On the contrary, our data in total phenols of lemon-, peach-, and sangria-flavored teas were 1.02, 1.36, and 1.13 higher than the content reported in their labels, respectively, and these differences could be attributed to the method use in determination of the phenolics.

\section{Conclusions}

Because of the increasing interest of consumers in the consumption of ready-to-drink teas with different flavors, it is necessary to know about their physicochemical and nutritional characteristics. There were differences between ready-to-drink flavored-colored commercial teas in physicochemical parameters, mineral composition, and nutraceutical properties. The $\mathrm{pH}$ values of tea samples were slightly acidic with values around $\mathrm{pH} 4$, titratable acidity was low with values near to $0.1 \%$, and color parameters of tea samples were wide variable with samples in pink, yellow, brown, and red colors. Citrus-flavored tea obtained the highest content of manganese, zinc, magnesium, potassium, and sodium, while lemon-, peach-, and blueberry-flavored teas obtained the highest levels of copper, iron, and calcium, respectively. In addition, manganese was detected only in citrus- and lemon-flavored teas. Citrus-, lemon-, sangria-, and rose petal-flavored teas obtained the highest content in total phenols, total flavonoids, total catechins, and total anthocyanins, respectively, while, lemon- and rose petalflavored teas showed the highest and lowest antioxidant capacity in DPPH, ABTS, and FRAP assays. The levels of sodium reported in labels of all samples were lower than those in data obtained in our analysis. The same was observed for total phenols in blueberry-, citrus-, and rose petalflavored teas, but total phenols of lemon-, peach-, and sangria-flavored teas were higher than the content reported in their labels. Finally, the results obtained in the present work give information to consumers for choosing flavoredcolored ready-to-drink tea based on the physicochemical, nutritional, and nutraceutical properties.

\section{Data Availability}

Data are available by request to corresponding author.

\section{Conflicts of Interest}

The authors declare that they have no conflicts of interest.

\section{Authors' Contributions}

Dolores Muy-Rangel and Guillermo Niño-Medina contributed equally to this work.

\section{References}

[1] T. K. Mondal, A. Bhattacharya, M. Laxmikumaran, and P. S. Ahuja, "Recent advances of tea (Camellia sinensis) biotechnology," Plant Cell, Tissue and Organ Culture, vol. 76, no. 3, pp. 195-254, 2004.

[2] M. G. Sajilata, P. R. Bajaj, and R. S. Singhal, “Tea Polyphenols as nutraceuticals," Comprehensive Reviews in Food Science and Food Safety, vol. 7, no. 3, pp. 229-254, 2008.

[3] R. Horanni and U. H. Engelhardt, "Determination of amino acids in white, green, black, oolong, pu-erh teas and tea products," Journal of Food Composition and Analysis, vol. 31, no. 1, pp. 94-100, 2013.

[4] W. C. Reygaert, "An update on the health benefits of green tea," Beverages, vol. 3, no. 4, p. 6, 2017.

[5] M. Chen, Y. Zhu, H. Zhang et al., "Phenolic compounds and the biological effects of Pu-erh teas with long-term storage," International Journal of Food Properties, vol. 20, no. 8, pp. 1715-1728, 2017.

[6] C. Cabrera, R. Artacho, and R. J. Gimenez, "Beneficial effects of green tea-a review," Journal of the American College of Nutrition, vol. 25, no. 2, pp. 79-99, 2006.

[7] D. Pasrija and C. Anandharamakrishna, "Techniques for extraction of green tea polyphenols: a review," Food and Bioprocess Technology, vol. 8, no. 5, pp. 935-950, 2015.

[8] D. Del Rio, L. Calani, F. Scazzina, L. Jechiu, C. Cordero, and F. Brighenti, "Bioavailability of catechins from ready-to-drink tea," Nutrition, vol. 26, no. 5, pp. 528-533, 2010.

[9] R. Arthur, 2017, https://www.beveragedaily.com/Article/2017/ 03/10/RTD-tea-high-growth-trajectory-predicted-to-continue.

[10] Association of Official Analytical Chemist (AOAC), Official Methods of Analysis of AOAC International, Association of Official Analytical Chemist (AOAC), Rockville, MD, USA, 16th edition, 1998.

[11] Commission Internationale De L'ecleirage, Cie 15: Technical Report: Colorimetry, Commission Internationale De L'ecleirage, Vienna, Austria, 3rd edition, 2004.

[12] ColorHexa, Color Encyclopedia: Information and Conversion: Computer Software, ColorHexa, 2017, http://www.colorhexa. $\mathrm{com} /$.

[13] G. Niño-Medina, J. D. Romo-Longoria, I. V. RamírezGonzález, O. O. Martínez-Reyna, and V. Urías-Orona, "Phenolic content and antioxidant capacity level in commercial Mexican lager beers," Journal of the American Society of Brewing Chemists, vol. 75, no. 2, pp. 156-158, 2017.

[14] E. S. M. Abdel-Aal and P. Hucl, "A rapid method for quantifying total anthocyanins in blue aleurone and purple pericarp wheats," Cereal Chemistry Journal, vol. 76, no. 3, pp. 350-354, 1999.

[15] J. J. López-Contreras, F. Zavala-García, V. Urías-Orona, G. C. G. Martínez-Ávila, R. Rojas, and G. Niño-Medina, 
"Chromatic, phenolic and antioxidant properties of Sorghum bicolor genotypes," Notulae Botanicae Horti Agrobotanici Cluj-Napoca, vol. 43, no. 2, p. 366, 2015.

[16] S. D. Sadler and P. A. Murphy, Food Analysis, Chapter 13, Springer Science, Basel, Switzerland, 1st edition, 2010.

[17] C. Tyl and G. D. Sadler, Food Analysis, Chapter 22, Springer Science, Basel, Switzerland, 5th edition, 2017.

[18] J. C. Griffiths, "Coloring food and beverages," Food TechnologyChicago, vol. 59, no. 5, p. 38, 2005.

[19] L. B. F. Lunkes and L. N. Hashizume, "Evaluation of the $\mathrm{pH}$ and titratable acidity of teas commercially available in Brazilian market," RGO-Revista Gaúcha de Odontologia, vol. 62, no. 1, pp. 59-64, 2014.

[20] S. D. Lin, J. H. Yang, Y. J. Hsieh, E. H. Liu, and J. L. Mau, "Effect of different brewing methods on quality of green tea," Journal of Food Processing and Preservation, vol. 38, no. 3, p. 1234, 2014.

[21] N. Zand, T. Christides, and E. Loughrill, Handbook of Mineral Elements in Food, Chapter 2, John Wiley and Sons, London, UK, 1st edition, 2015.

[22] T. Karak, F. R. Kutu, J. R. Nath et al., "Micronutrients (B, Co, $\mathrm{Cu}, \mathrm{Fe}, \mathrm{Mn}, \mathrm{Mo}$, and $\mathrm{Zn}$ ) content in made tea (Camellia sinensis L.) and tea infusion with health prospect: a critical review," Critical Reviews in Food Science and Nutrition, vol. 57, no. 14, p. 2996, 2017.

[23] M. Reto, M. E. Figueira, H. M. Filipe, and C. M. M. Almeida, "Chemical composition of green tea (Camellia sinensis) infusions commercialized in Portugal," Plant Foods for Human Nutrition, vol. 62, no. 4, p. 139, 2007.

[24] R. N. Gallaher, K. Gallaher, A. J. Marshall, and A. C. Marshal, "Mineral analysis of ten types of commercially available tea," Journal of Food Composition and Analysis, vol. 19, pp. S53-S57, 2006.

[25] C. Manach, A. Scalbert, C. Morand, C. Rèmèsy, and L. Jiménez, "Polyphenols: food sources and bioavailability," American Journal of Clinical Nutrition, vol. 79, no. 5, pp. 727-747, 2004.

[26] D. Huang, B. Ou, and R. L. Prior, "The chemistry behind antioxidant capacity assays," Journal of Agricultural and Food Chemistry, vol. 53, no. 6, pp. 1841-1856, 2005.

[27] B. J. Xu and S. K. C. Chang, "A comparative study on phenolic profiles and antioxidant activities of legumes as affected by extraction solvents," Journal of Food Science, vol. 72, no. 2, p. S159, 2007.

[28] M. Zia-Ul-Haq, S. Ahmad, S. A. Bukhari, R. Amarowicz, S. Ercisli, and H. Z. E. Jaafar, "Compositional studies and biological activities of some mash bean (Vigna mungo (L.) Hepper) cultivars commonly consumed in Pakistan," Biological Research, vol. 47, no. 1, p. 23, 2014.

[29] D. H. Kodama, A. E. S. S. Gonçalves, F. M. Lajolo, and M. I. Genovese, "Flavonoids, total phenolics and antioxidant capacity: comparison between commercial green tea preparations," Ciência e Tecnologia de Alimentos, vol. 30, no. 4, p. 1077, 2009.

[30] Z. Y. Chen, Q. Y. Zhu, D. Tsang, and Y. Huang, "Degradation of green tea catechins in tea drinks," Journal of Agricultural and Food Chemistry, vol. 49, no. 1, pp. 477-482, 2001.

[31] S. D. Lin, P. Udompornmongkol, J. H. Yang, S. Y. Chen, and J. L. Mau, "Quality and antioxidant property of three types of tea infusions," Journal of Food Processing and Preservation, vol. 38, no. 4, pp. 1401-1408, 2014. 

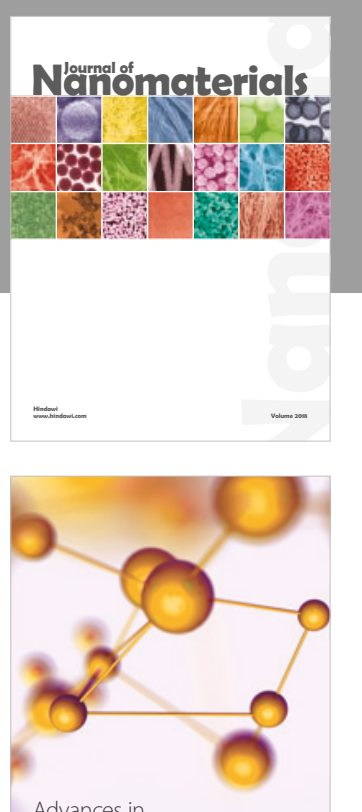

Physical Chemistry
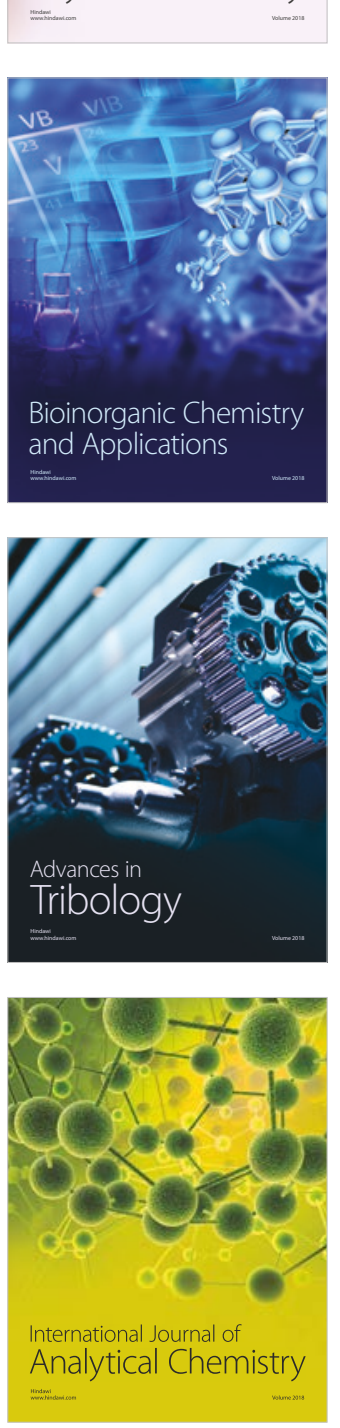

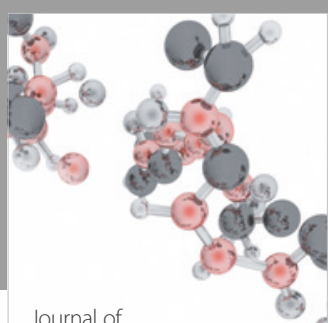

Analytical Methods

in Chemistry

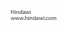

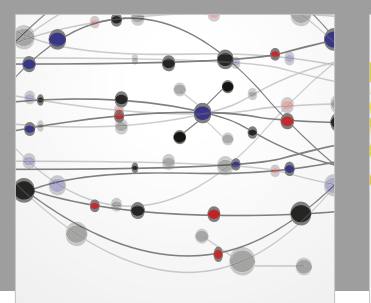

The Scientific World Journal

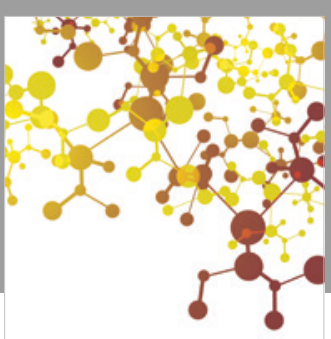

Journal of

Applied Chemistry
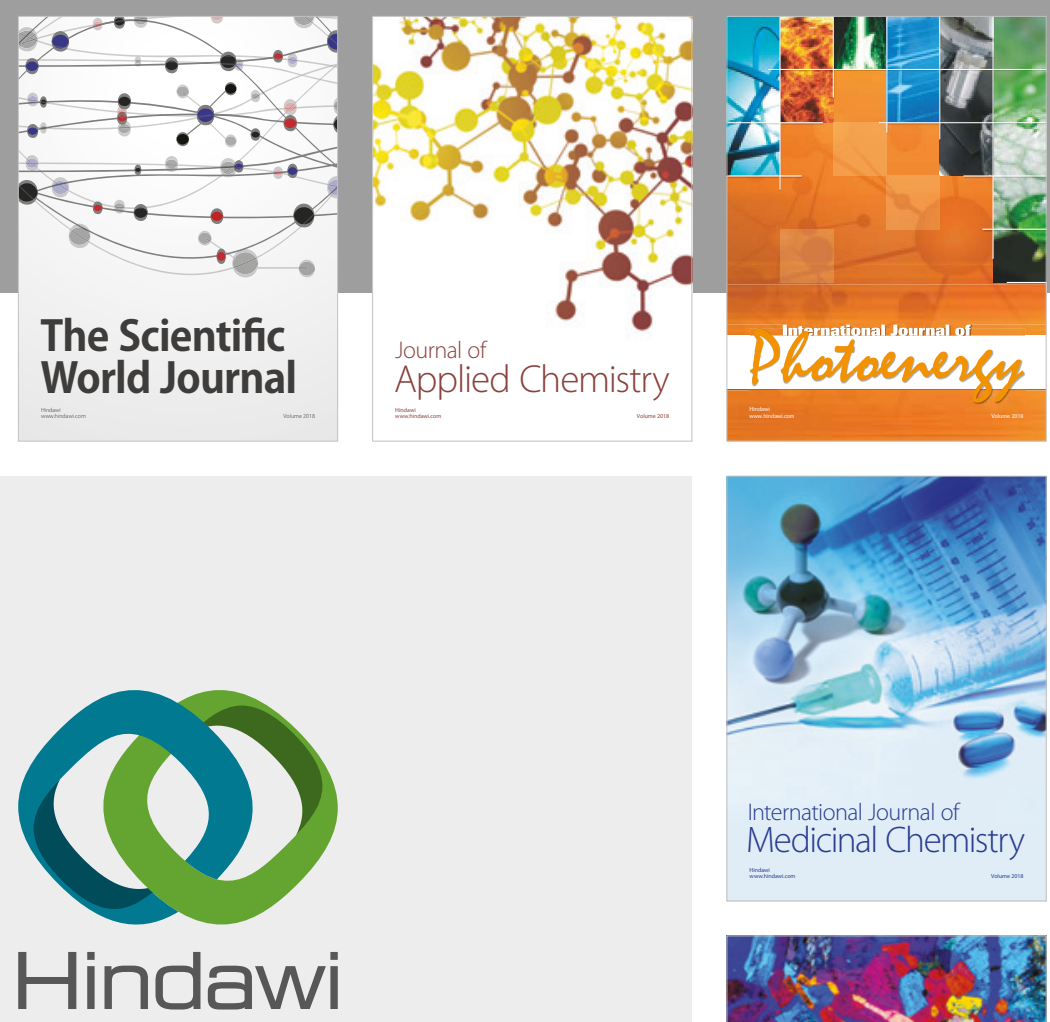

Submit your manuscripts at

www.hindawi.com
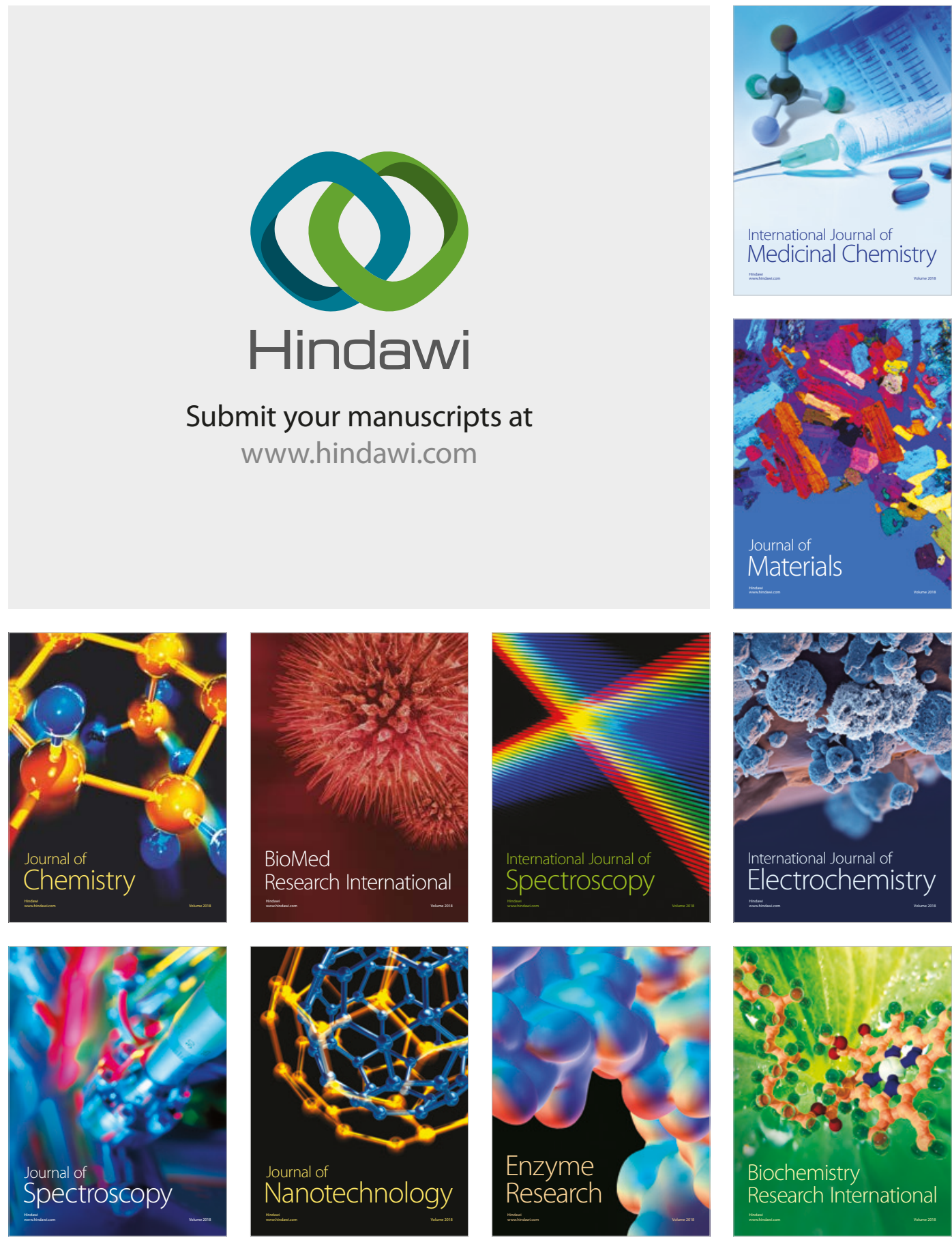
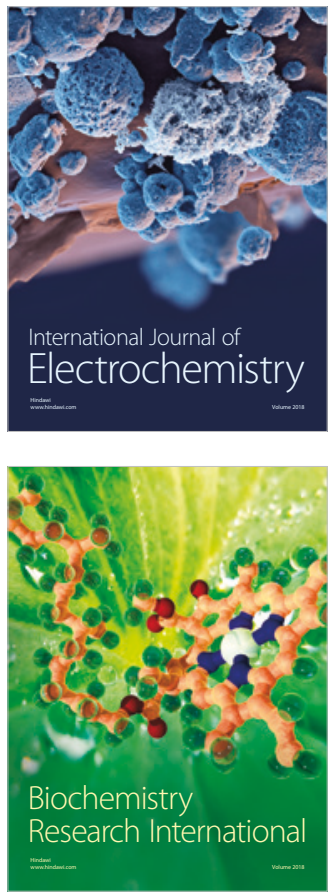